\title{
Understanding the Feasibility of the Common Set of Performance Management Planning Based on Hofstede's Framework of Cultural Dimension
}

\section{Yi Guo}

Hochschule Bremen, Germany

Email: szguoyi@foxmail.com

\begin{abstract}
Performance management is one of the most important parts of human resource management practice and policy. Multinational Corporations pay more attention to their performance management and to help their corporation becomes a high-performance organization. The performance management (PM) system is a necessary part of Multinational Corporation's management system. On the other hand, the performance system has close relationship with rewards, development and job analysis which is other important part of human resource management in multinational corporations. Multinational corporations work hard to improve their performance management practices ensuring their employees, teams and their business units complete their objective output. The employees and organizations have been driven by the important performance tools which impact both on individuals and team's performance. This paper introduces the multinational corporation's performance management system and compares the performance management characteristics and the feasibility of the common set of performance management planning of French companies and Chinese companies based on Hofstede's framework of cultural dimensions.
\end{abstract}

Keywords: performance management, multinational corporations, Hofstede's framework

\section{Introduction}

Employees and team's performance management in the international environment is more intricate than the performance management in a local environment. It has become a significant challenge to the multinational corporation. According to a study by Briscoe and Schuler (2009), it has three main reasons leading to the international performance management been more complex than the domestic performance management. Firstly, whether the domestic performance management practices and domestic culture influence the performance management systems develop in different directions or making organizations have only one standardized performance management system is an important question. It is hard to coexist in harmony with the performance management systems' managers and designers. Secondly, not only managers but also employees have to face the challenges of international assignees (IAs) in performance management. Thirdly, the performance management have been influenced by the local culture. For example, the cultural values influence the performance appraisal.

\section{Literature review}

Western companies` performance management systems have a significant influence on multinational corporation's performance systems (Briscoe \& Schuler, 2009). The western HR system has been used in the entire world because of the globalization. When the multinational corporation enter non-Western culture area, their western performance management system has to face the challenge in different cultural and national environment (Claus and Briscoe, 2006). Culture dimensions have been emphasized in the influence of culture on performance management (Briscoe \& Schuler, 2009). Hofstede's framework of cultural dimensions can identify cultural dynamics. There are five dimensions in Hofstede`s framework including Long Term Orientation, Individualism, Power-Distance, Masculinity and Uncertainty Avoidance (Hofstede, 1980). Sparrow and Hiltrop (1994) found that the two of the Hofstedes` culture dimensions including Power distance and Uncertainty avoidance are closet to the performance management.

Miller et al (2001) shows that in an individualistic cultural environment, the performance pays more attention to personal achievement and in the collectivist societies, the group-based achievement has been emphasised. In addition, the culture also determines the valued attributed. In the collectivistic cultures, performance belongs to situational-external component. Compare to the performance which belong to personal-internal component in the individualistic culture environment (Staw, 1980; Landrine and Klonoff, 1992; Markus, 1998). Different power distance culture has different 
display in performance management. In the high-power distance like France, the performance aims always set by staff higher-up the corporate structure. Compared to the nation in the low power distance like Germany, the negotiation between higher-up and employees determines the achieved objective (Barzantny and Festing, 2008).

Based on the Briscoe and Schuler (2009) study about the cultural convergence or divergence hypothesis, the people who support convergence hypothesis show the differences between different cultural is small. They found that the responsibility, monitoring and rewards in Japanese and American multinational corporations ' managers' management process is similar (Sullivan, Suzuki, and Kondo, 1985). And the performance management in different culture like Ghana and Nigeria has more similarities than dissimilarities (Arthur, Woehr, Adebowale and Strong 1995). In addition, Faulkner, D., Pitkethly, R. and Child, J. (2002) consider the best practices is convergence and the non-Western and Western management process demonstrate more similarities. On the other hand, the researchers who support divergence think the cultural differences have a deep influence on the performance system (Easterby, Malina and Yuan, 1995). The one size fits all performance system does not consider about local environment so cannot get good results. Although with the different tradition, legal and culture, the west companies enter the other nation, it is necessary to keep the local uniqueness (Galang, 2004). Mendonca and Kanungo (1996) indicate the Cultural fit framework is about how the socio-cultural environment affects the human resource management practices in different cultural environment.

\section{The international performance management based on Hofstede's framework of cultural dimensions}

Based on Hofstede's framework of cultural dimensions, French managers have get a high power distance score with 68 marks. Compare to British managers is just getting 35 marks and the China with 80. Sparrow and Hiltrop (1994) found that high power distance score reflect the big difference in French hierarchy system and the French managers can bear not being feared power. The French managers also get a high-level s of the uncertainty avoidance score with 86 . Compare to German managers get 65 and Chinese managers get 40. These high levels score reflect the French managers expect they can use planning process to control the future eventuality and manage the risk. It also reflects so that French manager attempts to make their tasks clearer and avoid the ambiguity and uncertainty in performance management. The relationship between subordinate and manager in French is painstaking (Poirson, 1993). Rojot (1990) give an example about the unsuccessful practice in the Management by Objectives which is a performance management tool. Because of the highpower distance, the French managers and subordinate concern the face-to-face dispute. This example shows that the AngloSaxon performance management method is not suit for the French organizations and the culture difference make a deep influence in performance management. Poirson (1993) found that in French company, senior managers are like a student in school, because their ideas are not accept and their boss had believed that he is the most clever man in the company.

According to Hofstede's framework of cultural dimensions, Chinese culture has a high-Power distance score (80). This culture characteristic leads to a deep influence of the Chinese performance management. The subordinates cannot discuss about their performance appraisal result with their manager. In the performance management, respecting for age and hierarchy is more important than the real performance result. On the Individualism dimensions, China only gets 20 marks. It shows that China is a Collectivist society and it is clear influence on Chinese performance management. According to Child (1991), the individual responsibility has been obstructed by the authority incline. On the other hand, the performance result has been decided centrally and with an acceptance of hierarchy. In the organization, there is a specific team, unit or group, which distinguish between outsiders and insiders (Gabrenya and Hwang, 1996). In the performance appraisal, there is a different standard between insiders and outsiders (Harzing and Pinnington, 2011). The relationship in the Chinese organization plays an important role in Chinese performance management. The employee who has got a good relationship in the organization can get a better result in performance appraisal than his real performance (Bennington and Bai, 2005). In addition, the Chinese performance appraisal emphasises moral facets like team recognition and political attitude (Bond 2001). However, Tayeb (2005) found that the relationship or networking skill mostly consist in small businesses. In the larger organisations, the interpersonal relationships and loyalties are not significant.

The French and Chinese culture both are high power distance cultures. However, there is a large difference in the other four dimensions, especially the Individualism dimension which is one of the biggest cultures influencing factors to performance management. Cooke (2008) makes a comparison with the performance management characteristic between French and Chinese. The performance management process and practices is different between the two countries. The French companies using competencies, 360-degree feedback and link to rewards. Compared to Chinese companies, they think outcomes are less important than effort traditionally. They use self and peer subordinate evaluations. The performance outcomes both include reward, but French companies use corrective performance approaches and total reward. 


\section{Case study of Alcatel Group}

To illustrate these points, this essay wills analysis a case study of global performance management system practice with a French company in China (Aidong, 2011). Alcatel Group is implementing a global performance management practice (GPMP) currently, so that all of Alcatel's global business units fit into a unified performance management framework and principles. This practice will help the parent company to control and coordinate the global performance management integration and action into a common subject.

Alcatel (Shanghai) Ltd., the China subsidiary of Alcatel, performance management practice better reflect the cultural conflict in global performance management system. In Alcatel (Shanghai) Ltd., most employees from traditional Chinese State-owned enterprises, whose management culture emphasize the relationships and collectivism. This management culture influences their performance management system. It has not very clear performance targets and appraisals are not very strict reward and punishment after the examination. Alcatel's corporate culture is more emphasis on competition and its focus on short-term results of performance appraisal, widening the reward and punishment and being more results oriented. Based on the competitive culture, dissatisfied new employees had could not identify or adapt and they chose to leave. However, in less than two years, Alcatel (Shanghai) Ltd. had cognizance of the different culture characteristics and invited the HR consulting company to improve their performance management system. Based on the Alcatel global performance management system, they just make a slight modified to adapt local culture. In Alcatel (Shanghai) Ltd., subordinates achieving the performance target, performance development and career development are the responsibility of managers, which are the most important factors in global performance management practice (GPMP). This allows the different subsidiaries of multinational corporations to operate in a unified performance management framework and gradually formed a unique corporate culture. Alcatel (Shanghai) Ltd. found a culture balance between convergence and divergence and its performance management system has been accepted by their headquarters and their employees.

This case shows that the cultural differences have a deep influence on performance management. Although they are part of the same cultural dimensions as high power distance between French and Chinese, the global common set of performance management preaches have to face the big challenge in culture different. However, in this case, the Alcatel tried to make little change in their global performance management systems to adjust to Chinese local performance management system and get success in their local subsidiary though it is difficult to combine the different countries' traditional performance management system which is based on the local culture environment. Without the cultural context, the performance management cannot do the best practice (von Glinow et al, 2002).

According to a study by Briscoe and Schuler (2009), to distinguish the performance process in local companies operations, the multinational corporation performance is called international PM system. The multinational corporation designed the international employee performance management system to support their global development strategy and help their employees and business units to achieve their global objectives.

Based on the Aidong (2011) study, when Alcatel extended its Global Performance Management Practice (GPMP) in Europe, the Force Distribution appraisal method in employee's performance management is strictly prohibited, because it is the prescripts of the European labour laws that employee's performance appraisal can only be based on actual performance. However, the Global Performance Management Practice (GPMP) in China, if not to force the distribution of the appraisal level, Chinese managers will score on a middle level or high level because oriental culture emphasizes the relationship in organization and the manager will not easily let their employees embarrassed. The performance appraisal result cannot distinguish employees' real performance, so it has to use the force distribution to be adjusted. By limiting the recognition of outstanding performance, they can motivate employee and encourage them to work harder to give more outstanding performance in the future.

\section{Conclusion}

To sum up, this paper introduces the Multinational Corporations performance management system and compares the performance management characteristics of French companies and Chinese companies based on Hofstede's framework of cultural dimensions. This paper practices and discusses the feasibility of the common set of performance management planning in French companies and Chinese companies and make a case study about a French company`s global performance management practice in Chinese subsidiary. Based on the discussion, there still have challenges in common set of performance management in different countries and the culture collision play an important role in the global performance management consolidation. The convergence and divergence of culture cannot be ignored in design global performance management system. From the theory discussion and the case study, the successful practice shows that the global performance management system is not perfect and suitable for every country, but through the advised change to 
adjust local performance management characteristics, the global performance management system can have a good effect in their local subsidiary.

\section{References}

[1] Arthur, W. Jr., Woehr, A., Adebowale D. J. Strong, M. Human resource management in West Africa: Practices and perspectives. The International Journal of Human Resource Management. 1995; 6: 347-366.

[2] Aidong, L. Performance management in multinational companies in China. Shanghai: Fudan University Press; 2006.

[3] Björkman, I., Xiucheng, F. Human resource management and the performance of Western firms in China. The International Journal of Human Resource Management. 2002; 13(6): 853-864. [Online] Available at: http://www.tandfonline.com/doi/abs/10.1080/09585190210134246 [Accessed: 8 January, 2012]

[4] Barzantny, C., Festing, M. Performance management in France and Germany. London: Routledge; 2008.

[5] Bai, X., Bennington, L. Performance appraisal in the Chinese state-owned coal industry. International Journal of Business Performance Management. 2005; 7(3): 275-287.

[6] Brewster, C, Larsen, H, Henrik, H. Human resource management in Europe: evidence from ten countries. The International Journal of Human Resource Management 1992; 3(3): 409-434.

[7] Brewster, C., Tyson. S. International comparisons in human resource management. London: Pitman; 1991.

[8] Claus, L. M, Briscoe, D. R. (2006) What we know and don`t know about performance management from an international/global perspective: A review and analysis of empirical research. Paper presented at the annual conference of the Academy of Management, August 11-16, Atlanta, GA.

[9] Cooke, F. L. Performance management in China. London: Routledge; 2008.

[10] Cooke, N. Multinational companies and global human resource strategies. Westport, CT: Greenwood Publishing Group; 2003.

[11] Dowling, P. J., Festing, M. International human resource management managing people in a multinational context. South-Western Cengage Learning; 2008.

[12] Faulkner, D., Pitkethly, R. Child, J. International mergers and acquisitions in the UK 1985-1994: A comparison of national HRM practices. International Journal of Human Resource Management. 2002; 13(1): 106-122.

[13] Galang, M. C. The transferability question: Comparing HRM practices in the Philippines with the US and Canada. International Journal of Human Resource Management. 2004; 15(7): 1207-1233.

[14] Hempel, S. Designing multinational benefits programs: The role of national culture. Journal of World Business. 1998; 33(3): 277-294. [Online] Available at: http://www.sciencedirect.com/science/article/pii/S1090951699800753 [Accessed: 8 January, 2012]

[15] Hilary, H. International human resource management. Chartered Institute of Personnel and Development; 2003.

[16] Kim, K. I., Park, H. and Suzuki N.Reward allocations in the United States, Japan, and Korea: A comparison of individualistic and collectivistic cultures. Academy of Management Journal. 1990; 33(1): 188-198. [Online] Available at: http://web.ebscohost.com/ehost/pdfviewer/pdfviewer?sid=8f48b3fa-a16d-4ca9-a7fc-8b45e5e01ec2\%40sessionmgr4\&vid=2\&hid=18 [Accessed: 8 January, 2012]

[17] Miao Zhang. Transferring human resource management across national boundaries: The case of Chinese multinational companies in the UK. Employee Relations. 2003; 25(6): 613-626.

[18] Poirson, P. The characteristics and dynamics of human resource management in France. London: Kogan; 1993.

[19] Selmer, J. International management in China: cross-cultural issues. Psychology Press; 1998. [Online] Available at: http://books.google.co.uk/books/about/International_management_in_China.html?hl=zh-CN\&id=36i22zJjMuAC [Accessed: 8 January, 2012]

[20] Sullivan, J., Suzuki, T. Kondo, Y. Managerial Theories and the Performance Control Process in Japanese and American Work Group. National Academy of Management Proceedings; 1985.

[21] Tayeb, M. H. International human resource management: a multinational company perspective. Oxford University Press; 2005.

[22] Von Glinow, M. A., Drost, E. Teagarden, M. Convergence of IHRM practices: lessons learned from a globally distributed consortium of theory and practice. Asia Pacific Journal of Human Resources. 2002; 40(1): 146-166. 